\title{
Quantum Seni: Implementasi Pendekatan Quantum Seni dalam Pelatihan Paduan Suara Nine's Voice di SMA Negeri 9 Manado
}

\author{
${ }^{1}$ Heskiel Manutty, ${ }^{2}$ Alrik Lapian, ${ }^{3}$ Meyltsan Maragani \\ Institut Agama Kristen Negeri Manado \\ 1'heskielmanutty@gmail.com, ${ }^{2}$ alriklapian@yahoo.com, ${ }^{3}$ ilzan_maragani@iakn- \\ manado.ac.id
}

\begin{abstract}
Abstrak
Tujuan penelitian ini adalah untuk menjelaskan bagaimana proses latihan paduan suara Nine"s Voice SMA negeri 9 Manado, mulai dari tahapan awal latihan sampai pada tahapanakhir bagaimana mempresentasikan lagu atau karya musik yang dilatih. Kemudian menjelaskan tentang bagaimana implementasi pendekatan Quantum seni dalam pelatihan paduan suara tersebut. Penelitian ini menggunakan metode penelitian deskriptif kualitatif yaitu pendekatan penelitian yang mengungkapkan situasi sosial tertentu dengan mendeskripsikan kenyataan secara benar, dari hasil penelitian ini didapati bahwa implementasi pendekatan quantum Seni dalam pelatihan Paduan Suara Nine"s Voice telah dilaksanakan mulai dari tahapan pra kondisi sampai pada tahapan akhir penyajian musik. Dari hasil penelitian ini maka direkomendasikan untuk menjadi salah satu bahan acuan yang bisa dipakai dalam pelatihan paduan suara.
\end{abstract}

Kata Kunci: Quantum Seni, Implementasi, Pelatihan Paduan Suara

\begin{abstract}
The purpose of this study was to explain how the Nine"s Voice choir training process at SMA Negeri 9 Manado, starting from the initial stages of training to the final stages of how to present the songs or musical works being trained. Then explain about how to implement the Quantum art approach in the choir training. This study uses a qualitative descriptive research method, namely a research approach that reveals certain social situations by describing reality correctly, from the results of this study it was found that the implementation of the Quantum Art approach in the Nine's Voice Choir training has been carried out starting from the pre-condition stage to the final stage. music presentation. From the results of this study, it is recommended to be one of the reference materials that can be used in choir training.
\end{abstract}

Keywords: Quantum Art, Implementation, Choir Training 


\section{Pendahuluan}

Pendidikan merupakan sebuah keniscayaan untuk dapat menghasilkan sosok manusia yang berkualitas baik dari sisi kognisi, afeksi dan psikomotorik. Oleh karena itu, pendidikan membutuhkan sebuah proses yang berkelanjutan dan tak pernah berakhir (long live education). Dengan kata lain pendidikan pada hakikatnya merupakan bagian integral dari kehidupan manusia, yang bertujuan untuk membentuk manusia menjadi sosok manusia yang sesungguhnya.

Dalam konteks pendidikan nasional, arah dan tujuan pendidikan telah dirumuskan dengan jelas. Tujuan dari pendidikan Nasional seperti yang diamanatkan dalam undang-undang Republik Indonesia nomor 20 Tahun 2003 tentang Sistem Pendidikan Nasional adalah berkembangnya potensi peserta didik agar menjadi manusia yang beriman dan bertakwa kepada Tuhan Yang Maha Esa, berakhlak mulia, sehat, berilmu, cakap, kreatif, mandiri, dan menjadi warganegara yang demokratis serta bertanggung jawab tujuan pendidikan nasional ini juga yang melandasi penyelenggaraan pendidikan di SMA Negeri 9 Manado.

Dalam rangka mencapai tujuan pendidikan nasional, maka SMA $\mathrm{N} 9$ Manado mewujudkannya dengan melaksanakan kegiatan intrakulikuler sebagai kegiatan utama proses belajar mengajar, dan kegiatan kokurikuler serta kegiatan ekstrakulikuler. Kegiatan ekstrakulikuler merupakan salah satu bagian dari sistem pembelajaran di sekolah-sekolah untuk mengoptimalkan capaian tujuan dari pendidikan nasional.

Salah satu kegiatan ekstrakulikuler di SMA N 9 Manado yang cukup maju dan dan menjadi kegiatan yang sangat digemari adalah paduan suara. Paduan suara di SMA N 9 Manado diberi nama "Nine's Voice" dibentuk sejak tahun 2007. Adapun pembentukan paduan suara ini sebagai salah satu wadah untuk memperkaya potensi siswa itu sendiri. Melalui paduan suara ini banyak prestasi yang dapat diraih oleh siswa, meskipun sebenarnya mereka harus pintar membagi waktu antara belajar setiap mata pelajaran yang menjadi tugas utama, tetapi mereka juga mampu menjaga suasana emosi dan semangat mereka dalam mengikuti latihan paduan suara. Meskipun siswa harus membagi waktu antara melaksanakan proses belajar mengajar dengan latihan paduan suara namun anak nine's voive tetap meraih prestasi dalam bidang akademik.

\section{Metode}

Penelitian ini menggunakan metode penelitian deskriptif kualitatif. Peneltian kualitatif adalah suatu pendekatan penelitian yang 
mengungkapkan situasi sosial tertentu dengan mendeskripsikan kenyataan secara benar, menggunakan kata-kata berdasarkan teknik pengumpulan data dengan analisis data yang relevan yang diperoleh dari situasi yang alamiah.

Metode Penelitian deskriptif digunakan dalam penelitian ini yaitu untuk mengungkapkan fenomena yang terjadi pada pelatihan Paduan Suara Nine's Voice sehingga mampu mendapatkan berbagai data sebagai informasi yang dibutuhkan. Metode kualitatif sebagai prosedur penelitian yang menghasilkan data deskriptif berupa kata- kata atau lisan dari orangorang atau perilaku yang dapat diamati.

\section{Hasil dan Pembahasan}

Berdasarkan hasil observasi peneliti di lokasi penelitian ditemukan bahwa, ternyata jumlah anggota Paduan Suara Nine"s Voice yang tercatat saat audisi dan diterima sebagai anggota adalah 50 orang, tetapi Tetapi yang sampai saat ini mengikuti latihan secara baik adalah 31 orang, hal ini dikarenakan kondisi pandemic covid-19.

Dalam pelaksanaan pelatihan paduan suara baik offline dan online pelatih menciptakan prakondisi latihan untuk mempersiapkan fisik dan terutama mental untuk mengikuti latihan paduan suara. Berdasarkan hasil wawancara dengan beberapa anggota paduan suara mereka mengatakan bahwa mereka sangat enjoy dalam melaksanakan latihan paduan suara dan merasa senang dalam mengikuti latihan paduan suara.

Berdasarkan hasil wawancara dengan salah seorang pelatih Nine"s Voice, implementasi pendekatan quantum seni sudah dilakukan saat penciptaan prakondisi, pelaksanaan latihan dan saat menampilkan karya musik kepada orang lain. $\mathrm{Di}$ lain kesempatan peneliti mewawancarai seorang ahli, yang juga sebagai akademisi, peneliti dan praktisi musik Prof.DR. Perry Rumengan,M.Sn, beliau mengatakan : "Banyak kali para pelatih paduan suara tidak menyadari bahwa ada beberapa hal yang dilakukannya dalam pemberian latihan adalah sudah termasuk kedalam penerapan Quantum Seni, karena pada hakekatnya implementasi Quantum Seni dalam latihan paduan suara adalah bagaimana mengirimkan gelombang positif dari pikiran dan perasaan pelatih kepada yang dilatih sehingga dia dapat memahami dan merasakan seperti yang dipikirkan dan dirasakan pelatih.

Dari apa yang disampaikan oleh para siswa anggota Nine,s Voice, Pelatih dan Bapak Kepala Sekolah serta tambahan wawancara kepada seorang ahli maka dapat memberi gambaran bahwa telah terjadi 
implementasi Quantum seni dalam proses latihan Paduan suara Nine"s Voice dan dampaknya bagi kemampuan siswa dalam menguasai lagu yang diajarkan serta mampu menyanyikannya dengan baik, walaupun untuk saat ini masih ada kendala-kendala seperti jaringan yg kurang baik saat Latihan online dan waktu Latihan yg tidak terlalu Panjang saat Latihan offline.

Paduan suara Nine"s Voice SMA Negeri 9 Manado sebagai salah satu paduan suara sekolah yang cukup eksis, juga melaksanakan program pelatihan paduan suara. Dalam setiap pelatihannya selalu dilakukan tahapan tahapan yang memungkinkan setiap anggota paduan suara dapat mengikutinya dengan baik, tahapantahapannya meliputi:

1. Prakondisi, pada tahapan ini meliputi persiapan ruangan, persiapan alat dan bahan yang dipakai dalam latihan, serta doa bersama sebelum masuk tahapan berikutnya.

2. Pemanasan, meliputi latihan melenturkan organ - organ tubuh yang berhubungan langsung dengan produksi suara seperti area mulut, rongga dada dan perut, serta organ - organ tubuh yang tidak berhubungan langsung dengan produksi suara seperti tangan yang tidak tegang, tumpuan dan posisi kaki saat bernyanyi dan posisi berdiri yang rileks.
3. Pernapasan, meliputi teknik bernapas dengan diafragma untuk melatih menahan nada - nada yang panjang, staccato dan legato.

4. Vokalisi, meliputi latihan mengambil nada - nada tinggi, sedang dan rendah dengan penempatan bunyi yang tepat, berenergi dan hidup (choral sound), frasering, diksi, serta melatih mengekspresikan bunyi yang gelap dan bunyi yang terang.

5. Latihan Inti, yaitu latihan notasi, syair dan interpretasi lagu.

6. Penutup, meliputi informasi-informasi seputar evaluasi latihan, jadwal latihan berikutnya dan doa tutup.

Dalam pelatihan paduan suara Nine's Voice, implementasi pendekatan quantum seni dilaksanakan pada beberapa tahapan dalam latihan, yaitu pada tahapan prakondisi, latihan pernapasan, vokalisi dan latihan inti yaitu belajar notasi, syair lagu dan intepretasi.

Prakondisi, pada tahapan ini implementasi quantum seni adalah menciptakan dan membangun suasana musikal dan kesadaran kolektif. hal ini dilakukan dengan cara memutar lagulagu paduan suara dari alat audio dengan volume yg lembut dan memberikan kesempatan kepada anggota paduan suara untuk rileks mendengar sambil melakukan sharing hal- hal yang ringan yang mencakup latihan. Hal baik yang terjadi adalah 
terciptanya suasana musikal dan kesadaran kolektif. Menurut Emile Durkheim kesadaran kolektif adalah sebuah sistem yang tetap ada di masyarakat, biasanya terbentuk karena adanya kepercayaan dan perasaan yang sama antar individunya, sehingga membentuk suatu ideologi atau pemikiran dan membentuk sistem.

Kesadaran kolektif yang
dimaksud disini adalah anggota paduan suara dalam alam bawah sadarnya terbangun sikap untuk mempersiapkan fisik dan psikis dalam mengikuti latihan. Arahan pelatih dan suara musik paduan suara yang diperdengarkan merupakan gelombang positif bagi anggota untuk membangun kesadaran itu, gelombang ini merupakan perwujudan quantum seni.

Latihan pernapasan; pada tahapan ini tidak hanya berlatih teknik pernapasan dalam paduan suara yang lazim dilakukan seperti memberdayakan area diafragma, tetapi melakukan implementasi quantum yaitu dengan melakukan meditasi. Menurut kamus besar bahasa indonesia meditasi adalah pemusatan pikiran dan perasaan untuk mencapai sesuatu.

Menurut Arbiyanto Hijriayan "meditasi adalah memusatkan pikiran pada suatu obyek tertentu yang dilakukan dengan kesadaran penuh, dirasakan bagaimana proses itu berefek pada tubuhnya".

$$
\text { Dalam tahapan ini anggota }
$$

paduan suara diarahkan untuk mengambil tempat tersendiri dengan memperhitungkan kenyamanan dan keamanan dirinya, kemudian memusatkan pikiran dan perasaan, menutup mata, mengambil nafas, menahan dan melepaskan udara dengan tenang, sambil hati terus menaikan syukur kepada Tuhan. Ini dilakukan secara berulang-ulang. hal baik yang terjadi adalah anggota Paduan suara lebih fokus, rileks dan segar.

\section{Dalam tahapan vokalisi dan} latihan inti, peranan pelatih sangat penting karena semua ucapan dan gerakan yang dibuat akan sangat berpengaruh terhadap penyanyi dan akan mempengaruhi proses akhir yaitu penyajian musik.

Sebagaimana realitas quantum yang berhubungan dengan otak manusia seperti yang diungkapkan oleh Dwi Marianto bahwa gelombang yang melintasi otak akan menjadi sesuatu yang kimiawi atau partikel. Maka setiap kata-kata dan motivasi positif dari seorang pelatih yang disampaikan secara berulang-ulang akan menjadi sugesti positif dan tersimpan dengan baik dalam memori para penyanyi. 


Sugesti adalah pengaruh
terhadap jiwa atau laku seseorang
dengan maksud tertentu sehingga
pikiran dan kemauan terpengaruh
olehnya. Menurut Abu Ahmadi inti dari
sugesti adalah didesaknya suatu
keyakinan kepada seseorang untuk
menerima pendapat atau nasehat orang
secara mentah- mentah yaitu pihak yang
mempengaruhi suatu keyakinan
pendapat atau anggapan kepada orang lain dan pihak yang dipengaruhi didesak untuk menurut dan menerima pendapat yang dikehendaki kepadanya. cara untuk menyugesti bisa berupa tapan mata, roman muka, teladan, gambaran atau visualisasi, suara, warna, dan slogan atau semboyan.

Dalam pelaksanaan latihan vokalisi dan latihan inti di paduan suara Nine's Voice implementasi quantum seni adalah dengan memberikan sugesti tangan, wajah,dan suara, baik dalam membuat ilustrasi dan visualisasi maupun dalam mengaba, sehingga para penyanyi memahami dan dapat mengikuti apa yang disampaikan, pada akhirnya saat mereka bernyanyi terlihat sangat menjiwai makna lagu.

\section{Kesimpulan}

Berdasarkan hasil penelitian
yang membahas Implementasi
Pendekatan Quantum Seni Dalam
Pelatihan Suara Nine"s Voice SMA

Negeri 9 Manado, dapat disimpulkan bahwa :

1. Proses yang dilakukan dalam pelatihan paduan suara Nine"s Voice meliputi Prakondisi, Pemanasan, Pernapasan, Vokalisi, Latihan Inti dan Penutup. Implementasi pendekatan quantum seni dalam Latihan paduan suara ini sudah dilaksanakan pada tahapan prakondisi, latihan pernapasan, vokalisi, latihan inti dan sampai pada penampilan paduan suara ini dalam menyajikan musik kepada orang lain.

2. Anggota paduan suara Nine"s Voice pada umumnya merasa enjoy dalam mengikuti pola-pola latihan dalam paduan suara ini, hal tersebut dikarenakanpenciptaan atmosfer latihan yang rileks dan menyenangkan.

3. Pelatih dan konduktor memegang peran penting dalam implementasi pendekatan quantum seni pada pelatihan Paduan Suara Nine"s Voice.

4. Implementasi pendekatan Quantum seni pada pelatihan Paduan Suara Nines Voice berdampak baik, hal ini dapat dilihat yaitu dengan dicapainya prestasi - prestasi yang baik di berbagai kompetisi. Capaian yang lain adalah banyak anggota paduan suara ini yang berprestasi di bidang akademik, serta alumni dari paduan suara ini yang 
berhasil memasuki Perguruan Tinggi-

Perguruan Tinggi terkenal.

\section{Kepustakaan}

Banoe Pono, Metode Kelas Musik. (Jakarta: PT Indeks,2013)

Djohan, Psikologi Musik. (Yogyakarta: Indonesia Cerdas, 2016)

Dwi Marianto Martinus, Quantum Seni: Fisika baru dan fisika quantum. (Dahara Prize).

Dwi Marianto Martinus, Memahami Peluang-Peluang Quantum dalam Seni,http://iournal.isi.ac.id/index.php lars/article/view/231 (diakses 23 april 2021 pukul 21.00 WITA )

Dwi Marianto Martinus, Seni dan Daya Hidup dalam Perspektif Quantum, http://diqilib.isi.ac.ad/7125/ (diakses 23 april 2021 pukul 22.12 WITA)

Dwi Marianto Martinus, Menempa Quanta Mengurai Seni. (Yogyakarta: ISI Yogyakarta, 2011)

Ganap Victor, Musik dalam Kultur Pendidikan. (Yogyakarta: Thafa Media, 2019)

Gibran Kahlil, Musik Dahaga Jiwa. (Yogyakarta: Fajar Pustaka Baru, 2000)

Khan Hazrat Inayat, Dimensi Mistik Musik dan Bunyi. (Yogyakarta: Pustaka Sufi, 2002)

Martopo hari, Musik sebagai Faktor Penting dalam Penerapan Metode PembelajaranQuantum, http://journal.unnes.ac.id/nju/indek x.php/harmonia/article (diakses 24 april 2021 pukul 05.10 WITA )

Merrit Stephanie, Simfoni Otak: 39 Aktivitas Musik Yang

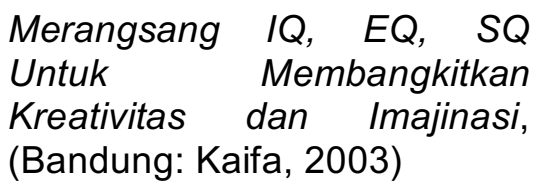

Moelyong lexy. J. Metodologi Penelitian Kualitatif (Bandung: Remaja Rosdakarya, 2006).

Mulyadi Seto, Basuki A. M. Heru, Rahardjo Wahyu, Psikologi Pendidikan. (Depok: RajaGrafindo Persada, 2016)

Rumengan Perry, Penerapan Sugesti dalam Teknik Conducting Paduan Suara, http://ejurnal-mapalusunima.ac.id/index.php/kompetensi/ article/view/1847 (diakses 25 Juni 2021 pukul 20.00 WITA)

Subaida Saputri, Filsafat Seni dan Estetika Menurut Hazrat Inayat Khan, http://repository.iainbengkulu.ac.id/ 5449/ (diakses 25 Juni 2021 pukul 22.00 WITA) 